\title{
PERNIKAHAN BEDA AGAMA DITINJAU DARI PERSPEKTIF ISLAM DAN HAM ${ }^{1}$
}

\author{
Ahmadi Hasanuddin Dardiri (09410551), Marzha Tweedo (10410483), \\ Muhammad Irham Roihan (10410251) \\ Jurusan Ilmu Hukum, Fakultas Hukum, Universitas Islam Indonesia
}

\begin{abstract}
ABSTRAK
Plurality in religion emerges interfaith marriage as debatable motion in Indonesia in general and Islam specif cally. Firstly, there are some different interpretations within fuqaha'or Islamic scholars concerning this matter inf uenced by some explanations provided in Holy Qur'an. Secondly, as Indonesia is not a secular state, the legality of marriage is regulated throughout the positive law that religious values are applicable. Thirdly, the notion regarding human rights also challenges the problem solving for couple proposing interfaith marriage. Nevertheless, the juridical and philosophical factors underlay the existence of interfaith marriage have vacuum of law. At any rate, this problem is really imminent to solve as marriage implicates child status either. In conclusion, vacuum of law concerning interfaith marriage shall be answered throughout existing law in Indonesia without setting aside the notion of human rights.

Key Words: Interfaith Marriage, Legality of Marriage, Human Rights

\section{PENDAHULUAN}

\section{Latar Belakang Masalah}

Dewasa ini, perbincangan tentang Hak Asasi Manusia (HAM) sangat gencar dibicarakan. Hal ini berawal dari kuatnya paham liberalisme yang dibawa-bawa oleh bangsa Barat. Kendati nilai-nilai HAM bersifat universal, namun beberapa hal masih menjadi perdebatan terkait dengan implementasi HAM tersebut. Salah satunya ialah hak untuk melangsungkan pernikahan dengan

kondisi pasangan yang memiliki agama yang berbeda. Secara sederhana, dalam Kamus Besar Bahasa Indonesia (KBBI), perkawinan/ pernikahan diartikan berdasarkan kata dasarnya menjadi melangsungkan pembentukan keluarga dengan lawan jenis. Pengertian tersebut tidak menjadi masalah ketika tidak menyentuh landasan idealisme, ketika seseorang atas dasar kepercayaannya tidak menjadikan suatu perkawinan itu dibolehkan atas dasar agama.
\end{abstract}


Padahal, dalam konsep HAM yang diusung oleh Barat, seseorang tidak boleh dibedakan hanya karena landasan agamanya, termasuk untuk melangsungkan pernikahan. Konsep HAM ini kemudian sangat bertentangan dengan konsep HAM dalam Islam. Dalam Islam, secara awam, membatasi boleh/tidaknya melakukan perkawinan beda agama dengan menyematkan sebutan kaf $r$, dzimmi, maupun orang-orang musyrik pada orang mukmin.

Hal yang demikian membuat tolak pikir umum, yakni haramnya perkawinan beda agama. Namun, dalam konteks sosial, khususnya di Indonesia yang sebanyak $85 \%$ lebih penduduknya beragama Islam², menjadi dinamika sosial yang patut mendapat perhatian dalam kasus perkawinan beda agama. Indonesia memiliki keberagaman dari berbagai aspek, tidak terkecuali agama yang menyebabkan adanya kemungkinan keberlangsungan pernikahan beda agama.

Pada Tahun 1980, sebanyak 24677 pasangan di Indonesia melakukan pernikahan beda agama. Selanjutnya pada tahun 1990, sebanyak 26688 pasangan di Indonesia melakukan hal yang demikian. Serta hasil terbaru yang ditemukan oleh penulis, pada tahun 2000, 2673 pasangan didata

2 Wikipedia, Agama di Indonesia, dimuat dalam http://id.wikipedia.org/wiki/Agama_ di_Indonesia, di akses pada tanggal 23 Januari 2012 sebagai pihak yang melakukan pernikahan beda agama. $^{3}$

Kendati data tersebut menunjukkan penurunan, namun dalam interval sepuluhtahun, dataselalumenunjukkan adanya pernikahan beda agama yang berlangsung. Sehingga penulis melakukan kesimpulan awal, bahwa di Indonesia yang merupakan Negara penuh keragaman termasuk agama terdapat pernikahan beda agama, tak terkecuali diantara orang Islam sendiri dengan orang di luar Islam. ${ }^{4}$

Dengan terjadinya dinamika sosial tersebut, disertai adanya pertanyaan masyarakat tentang kebolehannya, para ulama yang tergabung dalam majelis ulama Indonesia kemudian berusaha memberikan dalil agama untuk memberikan kepastian hukum terhadap kasus ini. Dalam fatwanya, MUI menyatakan dengan bernbagai landasan dalil bahwa perkawinan beda agama adalah haram sama sekali ${ }^{5}$, yang padahal bertentangan dengan jumhur ulama.

Dari berbagai kondisi sosial yang ada, serta faktor yuridis dan flosof $\mathrm{s}$

3 Dimuat dalam artikel berjudul Fakta Empiris Nikah Beda Agama di http://blog. umy.ac.id/retnoeno/2012/01/07/faktaempiris-nikah-beda-agama/, diakses pada tanggal 23 Januari 2012

Ibid

5 Faeshol Jamaluddin, Analisis Fatwa MUI Nomor :4/Munas VII/MUI/8/2005 tentang perkawinan beda agama, dimuat dalam http://idb4.wikispaces.com/file/view/ bu4001.pdf, diakses pada tanggal 23 Januari 2012 
tentang keberadan pernikahan beda agama yang ternyata setelah ditinjau lebih mendalam memiliki banyak kekosongan pemikiran, baik dalam pertentangan antara konsepsi HAM dalam kasus ini, bahkan hingga perbedaan pendapat para ulama, melandasi penulis untuk melakukan kajian terhadap judul ini.

\section{Rumusan Masalah}

Adapun rumusan masalah Karya Ilmiah ini adalah :

1. Apakah pernikahan beda agama diperbolehkan dalam Islam?

2. Bagaimana HAM memandang larangan pernikahan beda agama?

\section{Tujuan Penulisan}

Tujuan penulisan Karya IImiah ini adalah:

1. Untuk mengetahui bagaimana hukum pengaturan pernikahan beda agama dalam Islam yang memiliki tujuan perlindungan terhadap agama, jiwa, keturunan, dan harta

2. Untuk mengetahui bagaimana HAM memandang larangan pernikahan beda agama.

\section{Landasan Teori}

Landasan teori yang digunakan dalam penulisan karya ini didasarkan pada dalil-dalil al-Qur'an, yaitu:

QS Al-Maidah: 5

“...(Dan dihalalkan mangawini) wanita yang menjaga kehormatan diantara wanita-wanita yang beriman dan wanita-wanita yang menjaga kehormatan di antara orang-orang yang diberi Al Kitab sebelum kamu, bila kamu telah membayar mas kawin mereka dengan maksud menikahinya, tidak dengan maksud berzina dan tidak (pula) menjadikannya gundikgundik..."

QS. Al-Baqoroh: 221

"Dan janganlah kamu menikahi wanita-wanitamusyrik, sebelummereka beriman. Sesungguhnya wanita budak yang mukmin lebih baik dari wanita musyrik, walaupun dia menarik hatimu. Dan janganlah kamu menikahkan orang-orang musyrik (dengan wanitawanita mukmin) sebelum mereka beriman. Sesungguhnya budak yang mukmin lebih baik dari orang musyrik, walaupun dia menarik hatimu. Mereka mengajak ke neraka, sedang Allah mengajak ke surga dan ampunan dengan izin-Nya..."

QS. Al-Mumtahanah: 10

"Hai orang-orang yang beriman, apabila datang berhijrah kepadamu perempuan-perempuan yang beriman, maka hendaklah kamu uji (keimanan) mereka. Allah lebih mengetahui tentang keimanan mereka;maka jika kamu telah mengetahui bahwa mereka (benar-benar) beriman maka janganlah kamu kembalikan mereka kepada (suami-suami mereka) orangorang kafr. Mereka tiada halal bagi orang-orang kafr itu dan orang-orang kafr itu tiada halal pula bagi mereka. Dan berikanlah kepada (suami 
suami) mereka, mahar yang telah mereka bayar. Dan tiada dosa atasmu mengawini mereka apabila kamu bayar kepada mereka maharnya. Dan janganlah kamu tetap berpegang pada tali (perkawinan) dengan perempuanperempuan kaf $r$; dan hendaklah kamu minta mahar yang telah kamu bayar; dan hendaklah mereka meminta mahar yang telah mereka bayar. Demikianlah hukum Allah yang ditetapkanNya di antara kamu. Dan Allah Maha Mengetahui lagi Maha Bijaksana."

Selaindasaral-Qur'andiatas, dalam penulisan ini juga memuat landasan teori tentang HAM, yaitu: Teori Hugo de Groot yang menyatakan bahwa: a). Pada dasarnya manusia mempunyai sifat mau berbuat baik kepada sesama manusia; b). Manusia mempunyai hasrat kemasyarakatan, yaitu manusia bersedia mengorbankan kepentingan dirinya untuk kepentingan orang lain; c). ada 4 hal yang perlu diperhatikan dalam kehidupan bermasyarakat, yaitu: hindarkan dari milik orang lain, penuhilah janji, bayarlah kerugian yang disebabkan oleh diri sendiri, dan berilah hukum yang setimpal. ${ }^{6}$

\section{PEMBAHASAN}

\section{Pernikahan Beda Agama Dalam Islam}

1. Pengertian dan Hukum Pernikahan dalam Islam

Nikah dalam dalam Bahasa

6 Solly Lubis, Ilmu Negara, (Bandung: Mandar Maju. ,2001) hlm. 27-28
Arab bermakna (al-wath'u) yakni bersetubuh/berhubungan intim $^{7}$ atau juga bisa bermakna penyambungan atau penghubungan ${ }^{8}$. Sementara menurut kamus munawwir, arti lafaz nikah ialah berkumpul atau menindas, setubuh dan senggama. ${ }^{9}$

Nikah secara Terminologi di kalangan ulama ushul berkembang dua macam pendapat tentang arti lafaz nikah,yaitu:

Nikah menurut arti aslinya (arti hakiki) adalah setubuh dan menurut arti majazi (metaforis) adalah akad yang dengan akad ini menjadi halal hubungan kelamin antara pria dan wanita; demikian menurut golongan Hanaf.

Nikah menurut arti aslinya ialah akad yang dengan akad ini menjadi halal hubungan kelamin antara pria dan wanita, sedangkan menurut arti majazi ialah setubuh, demikian menurut ahli ushul golongan Syaf 'iyah ${ }^{10}$.

Meski pendapat diatas mengemukakan bahwa pada dasarnya pernikahan adalah akad yang diatur oleh agama untuk memberikan lakilaki hak memiliki penggunaan faraj (kemaluan) wanita dan seluruh

Zuhdi Muhdhor, Kamus Kontemporer (alAshri) Arab- Indonesia, (Yogyakarta : Multi Karya Graf ka, 2003), hlm. 1943

8 Ibid, hlm: 1026

9 A. W. Munawwir, Kamus al-Munawwir Arab-Indonesia Terlengkap, (Surabaya: Pustaka Progressif,2002), hlm. 1461

10 Abdurrahman al-Jaziri, al-Fiqh 'Ala alMadzahib al-Arba'ah, (Beirut: Dar al Fikr, t.th), Juz. IV, hlm. 3 
tubuhnya untuk berhubungan badan atau merupakan sesuatu yang hanya berurusan dengan duniawi saja, akan tetapi perkawinan dalam Islam memiliki pandangan bahwa pernikahan tidak hanya pengaturan aspek biologis semata, melainkan persoalan psikologis, sosiologis, dan teologis $^{11}$. Karena didalam pernikahan, terdapat pertanggungjawaban kepada istri dan anak, masyarakat bahkan kepada Allah.

Hukum pernikahan menurutjumhur ulama' adalah sunnah, sementara menurut pendapat sebagian besar pengikut Maliki menyatakan bahwa hukum pernikahan sunnah, sementara sebagian yang lain menyatakan wajib dan sebagian lain menyatakan mubah $^{12}$. Perbedaan pendapat tersebut dikarenakan adanya shighat amr (tanda perintah) dalam $\mathrm{f}$ rman Allah swt, QS an-Nisa:4 yang berbunyi:

"...fankihuu maa thoobalakum mina annisaa...". ${ }^{13}$

Selain itu juga ada hadist nabi Muhammad SAW yang mengatakan:

" tanaakahuu fa inni mukatsirun bikumul umam"14

Tanda perintah dua dasar hukum dalam Islam inilah yang menyebabkan

11 Karsayuda, Perkawinan Beda Agama, (Yogyakarta :Total Media Yogyakarta, 2006), hlm.69.

12 Imam al-Qodhi, Bidayatul Mujtahid wa Nihayatul Muqtashid, (Beirut :Dar al Fikr,2008), juz II, hlm. 3

13 Al-Qur'an dan terjemahanya, QS. an-Nisa: 3

${ }^{14}$ Imam Qodhi, Op. Cit, hlm. 3 terjadinya perbedaan pendapat dalam hukum pernikahan menurut penganut mazhab Maliki.

\section{Dasar Pernikahan Beda Agama dalam Islam}

Pernikahan beda agama diatur dalam Surat Al-Baqoroh :221 yang menerangkan larangan untuk menikahi orang musyrik sampai mereka beriman. ${ }^{15}$ Selain itu didalam surat Al-Mumtahanah ayat 10 terdapat adanya larangan mengembalikan wanita Islam yang hijrah dari makkah ke madinah kepada suami mereka di makkah dan meneruskan hubungan rumah tangga dengan perempuan kaf $r{ }^{16}$

Meski secara tegas dalam Islam terdapat pelarangan pernikahan beda agama dalam teori, namun dalam terdapat teori yang memunculkan adanya kesempatan untuk terjadinya pernikahan bukan satu golongan, yaitu antara umat Islam dengan wanita ahli kitab, pembolehan pernikahan dengan ahli kitab ini dimuat dalam surat alMaidah ayat 5 yang menerangkan bahwa adanya legalisasi pernikahan dengan wanita ahli kitab bagi kaum muslim. ${ }^{17}$

Dari seluruh teori yang telah dituliskan diatas, dapat ditarik kesimpulan bahwa pada dasarnya

\footnotetext{
${ }^{15}$ Lihat Landasan Teori hlm.3

16 Ibid

17 Ibid
} 
hukum Islam melarang adanya pernikahan beda agama. Di Indonesia, lima agama yang diakui memiliki pengaturan tersendiri terkait dengan pernikahan beda agama. Agama Kristen/Protestan memperbolehkan pernikahan beda agama dengan menyerahkan pada hukum nasional masing-masing pengikutnya. Hukum Katholik tidak memperbolehkan pernikahan beda agama kecuali mendapatkan izin oleh gereja dengan syarat-syarat tertentu. Hukum Budha tidak mengatur perkawinan beda agama dan mengembalikan kepada adat masing-masing daerah, sementara agama Hindu melarang keras pernikahan beda agama. ${ }^{18}$

\section{Hukum Pernikahan Beda Agama dalam Islam}

Pembahasan pernikahan beda agama ini akan dibedakan menjadi dua bagian, yaitu:

1. Pernikahan dengan Non Muslim/ kaf $r$.

2. Pernikahan dengan ahli kitab.

Dalam pembedaan dua kategori antara non muslim/kaf $r$ dengan ahli kitab ini memang terdapat sebuah pembedaan yang menimbulkan konsekuensi dalam hukumnya, non muslim/ kaf $r$ adalah orang-orang yang mengingkari Tuhan, ${ }^{19}$ sementara pengertian ahli kitab adalah orang

${ }_{18}$ Karsayuda, Op. Cit, hlm:87.

19 Zuhdi Muhdhor dan Atabik Ali, Op. Cit, hlm.1512 yang menganut salah satu agama Samawi yang mempunyai kitab suci seperti Taurat, Injil , dan Zabur. ${ }^{20}$

1. Pernikahan dengan non muslim/ kaf $r$

Def nisikaf rdanmuslimmerupakan def nisi yang sangat luas, para ulama' berpendapat bahwa istilah non muslim atau kaf $r$ disimpulkan oleh pakar AlQur'an, Syeikh Muhammad Abduh, segala aktif tas yang bertentangan dengan ajaran tujuan agama ${ }^{21}$. Tentu saja maksudnya tidak mengarah pada suatu kelompok agama saja, akan tetapi mencakup sejumlah agama dengan segala bentuk kepercayaan dan variasi ritualnya. Al Qur'an menyebutkan kelompok non muslim ini secara umum seperti terdapat dalam QS. surat Al-Hajj: 17

\section{"Sesungguhnya orang-orang} yang beriman, orang-orang Yahudi, orang-orang Shaabi-iin, orang-orang Nasrani, orang-orang Majusi dan orang-orang musyrik, Allah akan memberi Keputusan di antara mereka

20 Masri Elmahsyar Bidin, Prinsip Hubungan Muslim dan Non Muslim dalam Pandangan Islam, diakses pada tanggal 22 januari 2012 di ttp://www.google.co.id/url?sa=t\&rct=j\& $\mathrm{q}=$ pengertian+ahli+kitab+dalam+Islam\&so urce=web\&cd=1\&ved=0CB0QFjAA\&url= http\%3A\%2F\%2Fwww.ditpertais.net\%2Fa nnualconference\%2Fancon06\%2Fmakalah \%2FMakalah\%2520Masri.doc\&ei=gs4cT9 mHJoK4rAeysOGEDQ\&usg=AFQjCNHo OxR3-aLet3wVScgtKoQm7XcO3A.

${ }^{21}$ M. Quraish Shihab, M.Quraish Shihab Menjawab - 1001 Soal KeIslaman yang Patut Anda Ketahui,( Jakarta : Lentera Hati, 2008 ) hlm. 772. 
pada hari kiamat. Sesungguhnya Allah menyaksikan segala sesuatu". ${ }^{22}$

Dalam ayat Al Qur'an tadi terdapat lima kelompok yang dikategorikan sebagai non muslim, yaitu Yahudi, Nasrani, ash-Shabi'ah atau ashShabiin, al-Majus, al-Musyrikun. Masing-masing kelompok secara ringkas dapat dijelaskan sebagai berikut.

Pertama, Yahudi adalah kaum bangsa Israel yang mengamalkan ajaran nabi Musa/Taurat. Kedua, Nasrani/Nashara yang diambil dari nama Nashiroh (tempat lahir nabi Isa), mereka adalah kelompok yang mengajarkan ajaran nabi Isa. Ketiga, Ash-Shabi'ah, yaitu kelompok yang mempercayai pengaruh planet terhadap alam semesta. Keempat, Al-Majus yaitu para penyembah api yang mempercayai bahwa jagat raya dikontrol oleh dua sosok Tuhan, yaitu Tuhan Cahaya dan Tuhan Gelap yang masing-masingnya bergerak kepada yang baik dan yang jahat, yang bahagia dan yang celaka dan seterusnya ${ }^{23}$, dan Al-Musyrikun, kelompok yang mengakui ketuhanan Allah SWT, tapi dalam ritual mempersekutukannya denganyang lain seperti penyembahan berhala, matahari dan malaikat.

Dari pengertian Non muslim/kaf $r$ diatas, maka dapat disimpulkan bahwa lawan dari kata kaf $r$ adalah mukmin,

22 Al-Qur'an dan terjemahanya, QS Al Hajj: 17.

23 Quraish shihab, Tafsir Al-Misbah (Volume 9) (Jakarta :Lentera Hati , 2002), hlm. 29 orang yang mengimani Allah. Dalam surat Al-Mumtahanah menjelaskan bahwa adanya pelarangan untuk tetap meneruskan hubungan pernikahan dengan wanita kaf r, sampai mereka beriman kepada Allah. Larangan pernikahan beda agama dengan non muslim/kaf $r$ secara global telah disepakati oleh para ulama'24. Lebih Ianjut, Ibnu Katsir menjelaskan bahwa larangan pernikahan dengan non muslim atau kaf $r$ juga didasarkan pada surat Al-Baqoroh: 221. Beliau menjelaskan bahwa yang dimaksud dengan musyrik dalam ayat tersebut adalah penyembah berhala. ${ }^{25}$

Larangan pernikahan beda agama ini kemudian di rumuskan dalam Kompilasi Hukum Islam (KHI) di Indonesia. KHI yang diberlakukan dengan Instruksi Persiden (Inpres) Nomor 1 tahun 1991, melarang seorang muslim melakukan perkawinan beda agama. Larangan ini diatur dalam pasal 40 huruf c KHI. ${ }^{26}$ Sementara larangan pernikahan beda agama bagi wanita diatur dalam pasal $44 \mathrm{KHI}^{27}$ Secara Normatif larangan

${ }^{24}$ Imam al-Qodhi, Op.Cit, hlm. 36

25 Karsayuda, Op.Cit, hlm. 69.

${ }^{26}$ Dilarang melangsungkan perkawinan antara seorang pria dengan seorang wanita karena keadaan tertentu: a. karena wanita yang bersangkutan masih terikat satu perkawinan dengan pria lain; b. seorang wanita yang masih berada dalam masa iddah dengan pria lain; c. seorang wanita yang tidak beragama Islam.

27 Seorang wanita Islam dilarang melangsungkan perkawinan dengan seorang pria yang tidak beragama Islam. 
menikah beda agama ini tidak menjadi masalah, karena hal tersebut sejalan dengan ketentuan al-Qur'an yang disepakati oleh para fuqaha'. ${ }^{28}$

\section{Pernikahan dengan ahli kitab.}

Imam Syaf'i berpendapat bahwa ahlul kitab adalah orang Yahudi dan orang Nasrani keturunan orangorang Israel, tidak termasuk bangsabangsa lain yang menganut agama yahudi dan nasrani. Alasan yang dikemukakan oleh imam Syaf 'i adalah bahwa Nabi Musa dan Nabi Isa hanya diutus kepada bangsa mereka, bukan bangsa lain. Pendapat ini berbeda dengan Imam Hambali dan mayoritas pakar hukum Islam yang menyatakan bahwa siapapun yang mempercayai salah seorang nabi atau kitab yang pernah diturunkan oleh Allah, maka dia adalah ahlul kitab. Sementara sebagian Ulama' berpendapat bahwa ahli kitab adalah setiap umat yang memiliki kitab dan dapat diduga sebagai kitab suci. ${ }^{29}$

Pendapat terakhir ini kemudian diperluas lagi oleh para ulama' kontemporer, sehingga mencakup para agama-agama yang ada di Indonesia seperti Hindu dan Budha. Sementara menurut Ulama' Muhammad Rasyid Ridho dalam tafsir al manaar, setelah beliau memahami dan mepelajari segala yang berkaitan dengan hukum pernikahan beda agama, beliau menyimpulkan bahwa wanita musyrik

${ }^{28}$ Karsayuda, Op.Cit, hlm: 7

${ }^{29}$ M.Quraish Shihab, M. Quraish...,Op. Cit,hlm: 595. yang tidak diperbolehkan dinikahi yang disebutkan dalam Al-Qur'an QS AlBaqoroh: 221 adalah wanita musyrik arab.

Pendapat mengenai kebolehan menikahiwanitaahlikitabjugadidukung oleh pendapat jumhur ulama' yang mengatakan bahwa QS Al-Maidah: 5 merupakan bentuk pengkhususan dari QS Al-Baqoroh: 221, sehingga pernikahan dengan ahli kitab menjadi diperbolehkan ${ }^{30}$. Pendapat ini juga mendapat dukungan dari Syaf 'iyyah yang menolak bahwa QS Al-Maidah: 5 yang bersifat khusus dihapus oleh surat Al-Baqoroh:221, akan tetapi mereka mensyaratkan bahwa ahli kitab tersebut harus memenuhi kriteria tertentu. ${ }^{31}$

Pendapat mengenai larangan menikahi wanita ahli kita dirumuskan oleh sebagian ulama' yang menyatakan bahwa QS Al-Maidah: 5 merupakan bentuk khusus dari bentuk umumnya yaitu QS Al-baqoroh: 221 yang kemudian bentuk umum tersebut menghapus bentuk khusus. ${ }^{32}$ Senada dengan pendapat tersebut, sahabat nabi, Ibnu Umar, menyatakan bahwa pada zaman beliau, ajaran trinitas tidak lagi wajar dinamai dengan ahlul kitab, karena keyakinan tersebut merupakan bentuk penyekutuan terhadap Allah. ${ }^{33}$

Dari dua pendapat diatas, dapat

${ }^{30}$ Imam al-Qodhi, Op.Cit, hlm. 36

31 Karsayuda, Op.Cit, hlm. 79

32 Imam al-Qodhi, Op.Cit, hlm.36

33 M.Quraish Shihab, M. Quraish ...,Op.Cit, hlm. 597. 
diambil kesimpulan bahwa pada dasarnya para ulama' Islam berbeda pendapat dalam memandang hukum pernikahan beda agama terkait dengan seorang laki-laki muslim yang menikahi wanita non muslim yang ahli kitab. Perbedaan ini pada dasarnya berimplikasi terhadap huku pernikahan beda agama tersebut, yaitu halal dan haram.

HAM dan Implikasi Hukum Pernikahan Beda Agama

\section{Hakikat HAM}

Dalam $\mathrm{KBBI}^{34}$, hak diartikan sebagai kekuasaan untuk berbuat sesuatu. Dalam kronologis sejarah, perkembangan atas hak inilah yang kemudian memicu munculnya HAM dengan dasar liberalism. Pengakuan atas hak dalam konteks sejarah tidak terlepas dari teori terbentuknya Negara, yang meliputi teori ketuhanan, teori kekuasaan, teori perjanjian, serta teori kedaulatan. ${ }^{35}$ Dari masing-masing teori tersebut, mempunyai pandangan yang tersendiri dalam hakikat hak itu sendiri.

Dalam teori ketuhanan, pemegang hak tertinggi adalah Tuhan, sehingga semua kegiatan manusia ditujukan pada Tuhan. Sedangkan dalam teori kekuasaan pemegang hak tertinggi

34 Kamus Besar Bahasa Indonesia Off ine Versi 1.1 Freeware,2010 by Ebta Setiawan dengan mengacu pada data dari KBBI Daring (edisi III) di ambil dari http:// pusatbahasa.diknas.go.id/kbbi/

35 Solly Lubis, Op. Cit, hlm. 25 adalah penguasa. Munculnya teori kekuasaan dan praktiknya yang sangat menyengsarakan pihak yang dikuasai, memunculkan teori perjanjian sosial dalam ranah empiris. Teori ini merumuskan hak dan kewajiban atas dasar perjanjian antara pihak yang dikuasaidenganyangdikuasai. Namun, dalam tataran empiris pula, ternyata teori ini tidak mampu mengakomodir pihak lain yang tidak ikut melakukan perjanjian, terutama ketika perjanjian tersebut telah berlangsung lama sehingga pihak-pihak yang melakukan perjanjian tersebut sudah tidak mampu melakukan perjanjian.

Dari fakta sejarah tersebut, kemudian muncullah teori kedaulatan yang memandang hak penuh berada ditangan rakyat sedangkan penguasa berkewajiban untuk pengadaannya. Pandangan atas hak tersebut kemudian tidak berhenti, kuatnya paham liberalism dalam perkembangan sejarah tersebut memunculkan dua aliran liberalism, yaitu klasik dan modern. ${ }^{36}$ Dua cabang paham tersebut, tidak mengubah substansi bahwa manusia adalah yang utama. Pandangan tersebut kemudian memicu perkembangan pemikiran, bahwa hak manusia adalah yang utama sehingga tidak dapat direnggut oleh siapapun juga. Dalam pemikiran

${ }^{36}$ Wikipedia, Pemikiran Tokoh Klasik dalam Kelahiran dan Perkembangan Liberalisme Klasik, di muat dalam http://id.wikipedia. org/wiki/Liberalisme, di akses pada tanggal 22 Januari 2012. 
klasik beberapa doktrin seperti John Locke menyatakan bahwa hak manusia (HAM) meliputi, hak hidup, hak kemerdekaan, serta hak milik ${ }^{37}$

Berbeda pendapat dari John Locke, Thomas Hobbes hanya menyatakan bahwa HAM hanya ada satu, yaitu hak untuk hidup. Satu hal yang patut dicermati dari perbedaan ini, John Locke juga menyampaikan bahwa hak tersebut berasal dari Tuhan yang sifatnya kodrati. Artinya, menurut John Locke, HAM ada karena diberikan oleh Tuhan. Teori John Locke tentang HAM berdasar pemberian Tuhan ini sebenarnya berdasar atas teori hukum alam kodrati yang diajukan oleh Grotius (Hugo de Groot). ${ }^{38}$

Walaupun Hugo de Groot tidak secara spesif $k$ menyatakan hal tersebut berasal dari Tuhan, melainkan secara kodrati, namun hal tersebut memberikan pengertian bahwa pemikiran atas hak tersebut menjadi diakui kebenarannya kepada seluruh umat manusia. Walaupun demikian, awal munculnya pemikiran ini tetap mendapat tentangan dari Jeremy Bentham $^{39}$. Jeremy menganggap bahwa konsep HAM merupakan hak

37 Dimuat dalam artikel berjudul Pendapat Para Ahli Tentang HAM di website http:// nalhackerblog.blogspot.com/2010/03/ pendapat-para-ahli-tentang-ham.html, di akses pada tanggal 22 Januari 2012

38 Lihat Landasan Teori hlm. 4

39 Jeremy Bentham dikutip dalam buku nya K.M Smith Rhona dan Njal Hostmaelingen, Hukum HAM, (Yogyakarta: PUSHAM UII,2008), hlm. 13 kodrati yang sudah sepantasnya melekat pada manusia tidak memiliki parameter yang relevan. Secara nyata, tentangan terhadap Jeremy tersebut terbantahkan oleh sejarah. Dunia Internasional kembali berpaling pada teori kodrati yang menyatakan bahwa HAM adalah melekat, tidak diberi oleh penguasa manapun, melainkan ada karena manusia adalah manusia.

Kesepakatan atas teori tersebut muncul akibat adanya peristiwa holocaust oleh Nazi dalam perang Dunia II. ${ }^{40}$ Dalam proses tersebut, penguasa otoriter Jerman, Adolf Hitler membantai secara masal umat Yahudi di daerah kekuasaannya. Perasaan kejam atas tindakan ini menimbulkan kecaman dalam dunia masyarakat Internasional. Hal inilah yang kemudian menjadi buah pemikiran bahwa HAM dalam konteks ini hak hidup bukan karena pemberian penguasa, bukan karena hukum, namun melekat secara kodrati kepada manusia karena manusia adalah makhluk dengan martabat tertinggi ciptaan Tuhan.

\section{HAM di Indonesia}

Perkembangan HAM di Indonesia secara yuridis turut dicampuri oleh perkembangan dunia Hukum Internasional. Sudah menjadi suatu konsekuensi logis, bahwa kemerdekaan Indonesia yang bermula dari penjajahan berabad-abad menghasilkan sikap nasionalis untuk

${ }^{40}$ Ibid. 
mempertahankan hak atas rakyatnya. Di samping itu, pengaruh doktrin barat atas HAM kala itu turut mengambil peran, hingga menghasilkan dasar Negara Indonesia, yaitu UUD 1945 yang dalam pembukaannya mengakui eksistensi HAM secara eksplisit. ${ }^{41}$

Berlandas pada dasar Negara tersebut, pengakuan atas HAM utamanya meliputi kemerdekaan, yaitu bebas yang bertanggung jawab. Lebih lanjut, dasar Negara tersebut menyatakan kewajiban Negara untuk memenuhi kesejahteraan rakyatnya, memenuhi kesejahteraan masyarakatnya, serta melindungi segenap masyarakatnya. Sudah menjadi suatu konsekuensi logis bahwa munculnya kewajiban akan menyertakan hak pada pihak lain, yang dalam konteks ini rakyat. Hal ini kemudian mampu menyamakan semangat dari konstitusi tersebut sebagai semangat dalam mendirikan welfare state, yaitu negara yang tujuannya untuk mensejahterahkan rakyatnya. Perlu diingat, bahwa dalam dasar negara ini, penambatan hak tersebut didasarkan pada kelima sila ideologi Negara sebagaimana yang tercantum dalam paragraf keempat. Sehingga, hak apapun yang dimiliki, tidak bisa terlepas implementasi dan pertanggungjawabannya dari konteks Pancasila.

Lebih lanjut, pembukaan dari dasar

41 Undang-Undang Dasar R.I Tahun 1945, (Surakarta : Pustaka Mandiri),hlm. 4
Negara tersebut diimplementasikan dalam batang tubuh dasar Negara tersebut yaitu dalam pasal Pasal 5 ayat (1), Pasal 20 ayat (1), Pasal 26, Pasal 27, Pasal 28, Pasa129, Pasal 30, Pasal 31, Pasal 32, Pasal 33 ayat (1) dan ayat (3), dan Pasal 34 ditambah Ketetapan Majelis Permusyawaratan Rakyat Republik Indonesia Nomor XVII/MPR/I998 tentang HAM.

Indonesia kemudian meratif kasi piagam PBB sebagai sebuah undangundang yang sah berlaku di Indonesia. Ratif kasi tersebut diwujudakan dalam undang-undang nomor 39 tahun 1999. Ratif kasi ini dilakukan utamanya bukan karena Indonesia merupakan anggota PBB kala itu, melainkan terungkapnya beberapa kasus pelanggaran HAM berat saat pemerintahan Soeharto. ${ }^{42}$

Ratif kasi ini kemudian menimbulkankonsekuensi hukum bahwa seluruh pasal dalam DUHAM menjadi berlaku di Indonesia. Namun, dalam undangundang 39 tahun 1999 ditambahkan konsep ketuhanan dalam pasal 1 tentang ketentuan umum mengenai pengertian HAM itu sendiri. Hal ini kemudian membatasi implementasi HAM yang harus berdasar ketuhanan.

Secara umum HAM di Indonesia meliputi: a). Hak untuk hidup, b). Hak berkeluarga dan melanjutkan keturunan, c). Hak mengembangkan

${ }^{42}$ Deni K. Yusup, Kodif kasi UU No.39 Tahun 1999, dimuat dalam http://dkyusup. blogspot.com/2008/04/kodifikasi-uu-no39-tahun-1999.html, di akses pada tanggal 22 Januari 2012. 
diri, d). Hak memperoleh keadilan, e). Hak atas kebebasan pribadi (memilih dan mempunyai keyakinan politik, mengeluarkan pendapat di muka umum, memeluk agama masingmasing,tidakbolehdiperbudak, memilih kewarganegaraan tanpa diskriminasi, bebas bergerak, berpindah dan bertempat tinggal di wilayah Republik Indonesia), f). Hak atas rasa aman, g). Hak atas kesejahteraan, h). Hak turut serta dalam pemerintahan, i). Hak wanita, j). Hak anak.

\section{HAM dalam Islam}

Pertentangan antara HAM dan Islam dimulai dari adanya perbedaan konsep mendasar tentang asal HAM itu sendiri. Dewasa ini, HAM lebih mengedepankan aspek kebebasan manusia atau liberalisasi atas manusia. Padahal dalam Islam, hal tersebut tidak bisa diakui sepenuhnya, karena dalam agama ini terdapat ajaran yang menyatakan bahwa Tuhan(Allah SWT) adalah pemilik alam semesta, sehingga tidak satupun manusia yang bebas melakukan sesuatu kecuali atas izin-Nya.

Pembahasan HAM dalam Islam secara substantif terdapat dalam ajaran agama Islam itu sendiri, yang dalam konteks ini mewajibkan seseorang untuk menghargai hak orang lain. Seperti ajaran dilarang membunuh, dilarang mencuri, dan sebagainya. Kodif kasi tentang HAM dimulai dari munculnya Piagam
Madinah, yaitu perjanjian semacam kontrak politik antara Rasulullah Muhammad SAW dengan penduduk Madinah yang menempatkan Rasul sebagai pemimpinnya.

Dalam Piagam Madinah terdapat beberapa konsepsi dasar terhadap hak yang tertera dalam paragraph "Pembukaan". Terdapat paling tidak lima makna pokok kandungan alenia tersebut, yaitu penempatan namaAllah SWT pada posisi teratas, perjanjian masyarakat (social contract) tertulis, kemajemukan peserta, keanggotaan terbuka (open membership), dan persatuan dalam ke-bhineka-an (unity in diversity).

HAM yang terkandung dalam Piagam Madinah dapat dibagi menjadi tiga hal, yaitu hak untuk hidup, hak dalam kebebasan, dan hak mencari kebahagiaan.

Dari pembahasan tersebut, dapat disimpulkan bahwa agama Islam mengakui konsep hak yang melekat darimanusiayang diberikan oleh Tuhan kepada manusia. Hal ini menimbulkan konsekuensi logis, bahwa Tuhanlah yang boleh menetapkan mana yang bisa dimiliki haknya oleh manusia dan mana yang tidak. Secara substantif, HAM dalam Islam lebih diarahkan pada implementasi kewajiban asasi manusia, yaitu keharusan manusia untuk tidak melakukan sesuatu pada manusia lainnya. Dalam hal ini, pedoman melakukannya terdapat dalam agama Islam itu sendiri, 
sedangkan kodif kasi khususnya terdapat dalam Piagam Madinah yang merumuskan hak-hak yang dapat diperoleh oleh umat manusia.

\section{Analisa Pelanggaran HAM dalam Pernikahan Beda Agama}

Indonesia adalah masyarakat yang plural. Artinya, terdiri dari berbagai macam suku, ras, dan kepercayaan. $\mathrm{Hal}$ ini menimbulkan berbagai dampak sosial salah satunya tentang perkawinan. Dalam hal ini, dampak sosial berusaha ditekan dengan munculnya UU No. 1 Tahun 1974 tentang Perkawinan yang merupakan unif kasidariseluruh hukum pernikahan yang ada di Indonesia. Permasalahan kemudian muncul, ketika pembatasan pernikahan atas dasar UU ini pasal 2 ayat 1 menyatakan bahwa "Perkawinan adalah sah apabila dilakukan menurut hukum masing-masing agama dan kepercayaannya itu".

Dalam konsep HAM barat yang dewasa ini sangat digencarkan, pernikahan dirumuskan dalam instrumen hukum internasional yaitu Universal Declaration of Human Rights 1948 (DUHAM), tepatnya pada pasal 16 dalam 3 ayat, yaitu :

laki-laki dan perempuan yang sudah dewasa dengan tidak dibatasi kebangsaan, kewarganegaraan atau agama berhak untuk menikah dan untuk membentuk keluarga. Mereka mempunyai hak yang sama dalam soal perkawinan, di dalam masa perkawinan dan di saat perceraian;

perkawinan hanya dapat dilaksanakan berdasarkan pilihan bebas dan persetujuan oleh kedua mempelai; dan

keluarga adalah kesatuan yang alamiah dan fundamental dari masyarakat dan berhak mendapatkan perlindungan dari masyarakat dan negara.

Dalam konsep tersebut, HAM diartikan memberi kebebasan untuk melakukan pernikahan tanpa memandang agama. Hal ini bertentangan dengan UU No. 1 Tahun 1974, yang menyatakan harus dilakukan sesuai dengan agama masing-masing. Penjelasan atas UU ini kemudian diperkuat dengan adanya UU No 39 Tahun 1999. Dalam pasal 50 UU ini, tercantum klausa bahwa "Wanita yang telah dewasa dan atau telah menikah berhak untuk melakukan perbuatan hukum sendiri, kecuali ditentukan lain oleh hukum agamanya."

Dalam tataran yuridis, sebuah Negara yang telah meratif kasi suatu instrument HAM memiliki suatu kewajiban untuk melaksanakan aturan tersebut. Namun demikian, terdapat kebebasan dalam ratif kasi yang memberikan peluang dalam hukum untuk dapat diaplikasikan dalam sistem hukum suatu Negara. Dengan adanya pengertian tersebut, maka secara yuridis, tidak menjadi suatu masalah ketika UU No. 39 Tahun 1999 serta UU No. 1 Tahun 1974 yang berbeda 
dari DUHAM sebagai instrumen dasar HAM.

Namun, tataran yuridis tersebut harus mampu dijelaskan dalam tataran $\mathrm{flosof} s$ tentang HAM, mengingat DUHAM sendiri hanya merupakan kodif kasi rasional umat manusia atas HAM. Begitu pula UU No. 39 Tahun 1999, UU No 1 Tahun 1974 bahkan UUD 1945. Dalam tataran flosof s, pengertian atas hak serta pernikahan itu sangat penting artinya. Dalam pengertian HAM dalam kajian ini terdapat dua kubu penting, pertama menurut konsepsi internasional yang kedua menurut konsepsi Islam.

Dalamkonsep Internasional, doktrin sepakat menyatakan bahwa HAM merupakan hak kodrati yang dimiliki oleh umat manusia karena derajatnya yang tinggi sebagai makhluk ciptaan Tuhan. Sedangkan dalam konsep Islam, HAM ditempatkan berdasar ketuhanan, umumnya diwujudkan dengan penghormatan terhadap orang lain dalam bentuk kewajiban untuk tidak melakukan penghilangan daripadanya. Dalam pengertian kedua konsep tersebut terdapat beberapa persamaan, yang pertama HAM ada untuk manusia karena Tuhan. Dengan demikian, fungsi kodrati bahwa HAM melekat pada seluruh umat manusia menjadi jelas, karena setiap manusia adalah ciptaan Tuhan. Lebih lanjut, secara eksplisit pengertian HAM dalam dunia internasional atas dasar pengertian tersebut, akhirnya juga menyepakati bahwa HAM merupakan pemberian Tuhan serupa dengan konsepsi HAM dalam Islam.

Pernikahan sendiri dalam DUHAM berdasar rasionalisme dan liberal menghasilkan paham sekuler yang berusaha memisahkan dunia dengan agama yang menghasilkan bebasnya perkawinan beda agama. Berbeda dengan konsep Islam, yang menyatakan bahwa perkawinan dilaksanakan karena hak untuk nikah sendiri diberikan oleh Tuhan. Maka menurut Islam, kapan, siapa, dimana, bagaimana, kenapa seseorang itu melakukan pernikahan adalah hak Tuhan untuk menetapkan mana yang akan diserahkan pada manusia dalam kepengurusannya.

Penjabaran makna pernikahan dalam DUHAM sendiri kemudian menjadi tidak relevan ketika mengingat dasar $f$ losof $s$ pengadaannya. Bahwa DUHAM mengakui adanya Tuhan pemberihaktersebut, namunkemudian mengapa agama sebagai ajaran Tuhan tidak dijadikan landasan.

\section{Implikasi Pernikahan Beda Agama terhadap Status Anak}

Anak adalah belahan jiwa dan potongan daging orang tuanya. ${ }^{43}$ Begitu pentingnya eksistensi akan lambang penerus dan lambang keabadian ini, maka Allah SWT

${ }^{43}$ Yusuf al-Qadhawi, Halal dan Haram dalam Islam, (Surabaya: PT Bina Ilmu, 1976), hlm. 256-158 
mensyari'atkan adanya pernikahan. Pensyari'atan pernikahan memiliki tujuan antara lain untuk berketurunan yang baik, memelihara nasab, menghindarkan diri dari penyakit dan menciptakan keluarga yang sakinah. ${ }^{44}$ Pernikahan beda agama yang terjadi antara dua insan manusia, tentunya memiliki dampak atau implikasi pada status anak dikemudian hari. Implikasi tersebut dapat diidentif kasikan dengan status anak yang bukan menjadi anak kandung, karena dalam pembahasan di atas hukum pernikahan beda agama dalam Islam adalah dilarang (haram)

Status anak 'haram' akibat pernikahan beda agama pada prinsipnya, penulis tidak sependapat dengan istilah tersebut, karena di samping istilah itu tidak dikenal dalam hukum positif, juga terdengar kurang etis bagi yang bersangkutan. Selain itu, kelahiran seorang anak di dunia ini tidak pernah dikehendaki oleh anak itu sendiri. Kelahirannya semata-mata merupakan kehendak sadar kedua orang tuanya. Terhadap anak tersebut lebih tepatnya dapat dikatakan sebagai anak yang lahir di luar perkawinan yang sah.

Dalam Kompilasi Hukum Islam selain dijelaskan tentang kriteria anak sah atau anak yang dilahirkan dalam ikatan perkawinan yang sah, sebagaimana yang dicantumkan dalam Pasal 99 Kompilasi Hukum

44 Wahbah al- Zuhailiy, Al-Fiqh al- Islamiy wa Adillatuhu, (Beirut: Dar al-Fikr, 1997), cet. Ke-2 . hlm. 11
Islam, yang berbunyi : "bahwa anak yang sah adalah anak yang dilahirkan akibat perkawinan yang sah dan hasil pembuahan suami isteri yang di luar rahim dan dilahirkan oleh isteri tersebut," ${ }^{45}$ juga dikenal anak yang lahir di luar perkawinan yang sah, seperti yang tercantum dalam Pasal 100 Kompilasi Hukum Islam bahwa "anak yang lahir di luar perkawinan hanya mempunyai hubungan nasab dengan ibunya dan keluarga ibunya". ${ }^{46}$

Dalam pasal 42 Bab IX Undangundang Nomor 1 Tahun 1974 juga dijelaskan bahwa anak yang sah adalah anak yang dilahirkan dan atau sebagai akibat perkawinan yang sah. Yang termasuk dalam kategori pasal ini adalah:

a. Anak yang dilahirkan oleh wanita akibat suatu ikatan perkawinan yang sah.

b. Anak yang dilahirkan oleh wanita di dalam ikatan perkawinan dengan tenggang waktu minimal 6 (enam) bulan antara peristiwa pernikahan dengan melahirkan bayi.

c. Anak yang dilahirkan oleh wanita dalam ikatan perkawinan yang waktunya kurang dari kebiasaan masa kehamilan tetapi tidak diingkari kelahirannya oleh suami.

Salah satu implikasi terhadap status anak yang lain yang dilahirkan

45 Undang-Undang R.I Nomor 1 Tahun 1974 Tentang Perkawinan dan Kompilasi Hukum Islam (Kesindo Utama : Surabaya, 2010 ), hlm.226

46 Ibid, hlm. 226 
melalui proses pernikahan yang tidak sah (karna larangan pernikahan beda agama) adalah adanya pengakuan bahwa anak tersebut adalah anak hasil perzinahan. Hasanayn Muhammad Makluf membuat terminologi anak zina sebagai anak yang dilahirkan sebagai akibat dari hubungan suami isteri yang tidak sah. Hubungan suami isteri yang tidak sah sebagaimana dimaksud adalah hubungan badan (senggama/ wathi') antara dua orang yang tidak terikat tali pernikahan yang memenuhi unsur rukun dan syarat nikah yang telah ditentukan. ${ }^{47}$

Meskipun istilah "anak zina" merupakan istilah yang populer dan melekat dalam kehidupan masyarakat, namun Kompilasi Hukum Islam tidak mengadopsi istilah tersebut untuk dijadikan sebagai istilah khusus di dalamnya. Hal tersebut bertujuan agar anak hasil dari hubungan zina, tidak dijadikan sasaran hukuman sosial, celaan masyarakat dan lain sebagainya, dengan menyandangkan dosa besar ibu kandungnya dan ayah anak tersebut kepada dirinya, selain itu juga bertujuan untuk menunjukkan identitas Islam bahwa Islam tidak mengenal adanya "dosa warisan".

Berdasarkan def nisi dan pendekatan makna "anak hasil zina" di atas, maka yang dimaksudkan dengan anak hasil zina dalam pembahasan

47 Abd. Aziz Dahlan, Ensiklopedia Hukum Islam, PT. Ichtiar Baru Van Hoeve, Jakarta, 1999, hlm. 40. ini adalah anak yang janin atau pembuahannya merupakan akibat dari perbuatan zina, maupun anak yang dilahirkan di luar perkawinan yang sah, sebagai akibat dari pernikahan beda agama.

Anak yang lahir di luar pernikahan yang sah adalah anak yang dilahirkan oleh seorang perempuan, sedangkan perempuan itu tidak berada dalam ikatan perkawinan yang sah dengan priayang menyetubuhinya. Sedangkan pengertian anak yang lahir akibat dari pernikahan beda agama adalah hubungan seorang pria dengan seorang wanita berbeda agama yang dapat melahirkan keturunan atau anak sedangkan hubungan mereka tidak dalam ikatan perkawinan yang sah menurut hukum positif dan agama yang dianutnya.

Terkait status anak seperti yang telah dipaparkan diatas, menurut hukum syari'ah, anak hasil zina itu suci dari segala dosa orang yang menyebabkan eksistensinya di dunia ini, sesuai dengan hadis Nabi Muhammad Saw yang artinya:

Semua anak dilahirkan atas kesucian/kebersihan (darisegala dosa/ noda) dan pembawaan beragama tauhid, sehingga ia jelas bicaranya. Maka kedua orang tuanyalah yang menyebabkan anaknya menjadi Yahudi, atau Nasrani atau Majusi. (Hadis riwayat Abu Ya'la,al-Thabrani dan al-Baihaqi dari al-Aswad bin Sari'). 
Karena itu, anak hasil zina harus diperlakukan secara manusiawi, diberi pendidikan, pengajaran dan keterampilan yang berguna untuk bekal hidupnya di masyarakat nanti.

\section{PENUTUP}

\section{Kesimpulan}

Berdasar atas rumusan masalah yang telah kami buat, maka kami mendapatkan kesimpulan sebagai berikut:

1. Bahwa dalam Islam, pernikahan beda agam pada dasarnya dilarang. Akan tetapi terdapat pengecualian apabila pasangan laki-laki adalah seorang mukmin dan pasangan perempuan adalah ahli, pada pasangan semacam inilah para ulama' berbeda pendapat dalam menghukumi. Kaidah ushul $\mathrm{fqh}$ " idza ijtama'a baina al halal wal haram ghuliba al haram" bisa dijadikan solusi dalam pengambilan hukum sebagai bentuk ihtiyaat atau kehati-hatian dalam pelaksanaan syariah Islam.

2. Bahwa HAM manusia pada dasarnya merupakan hak kodrati yang diberikan tuhan kepada manusia, maka tidak rasional apabila hak kodrati tersebut menyimpang dari aturan dan ketentuan tuhan. Begitupula dalam Islam, dengan adanya aturan Allah, maka HAM tersebut sudah tentu tidak boleh bertentangan dengan ajaran yang diperintahkan oleh allah SWT.

\section{Saran}

Hukum Islam pada dasarnya dibuat untuk mencapai maqoosid syari'ah, yaitu hifd ad-din,hifd an-nafs, hifd alaql, hifd an-nafs dan hifd al-maal. Oleh karena itu, dalam perumusan hukum Islam haruslah memperhatikan aspek ini. Hukum pernikahan beda agama ini haruslah berorientasi terhadap maqosid syari'ah tersebut dan memperhatikan dampak terhadap status anak dan hak anak dalam waris serta nikah. Melihat pada kenyataan di atas, Penulis menyarankan adanya kaidah ushul yang digunakan dalam pengambilan hukum dalam perbedaan ini, kaidah "idza ijtama'a baina al halal wal haram ghuliba al haram"48. Kaidah ini mungkin bisa menjadi penengah dari berkumpulnya hukum yang menghalalkan sesuatu dan mengharamkan sesuatu sebagai sebuah tindakan berhati-hati dalam menentukan sebuah hukum, sehingga kita sebagai umat Islam tetap terjaga dalam segala aturan yang telah ditetapkan oleh Allah SWT.

\section{DAFTAR PUSTAKA}

Abdul Aziz Dahlan, 1999, Ensiklopedia Hukum Islam, PT. Ichtiar Baru Van Hoeve, Jakarta.

Abdurrahman al-Jaziri, al-Fiqh 'Ala alMadzahib al-Arba'ah (Juz. IV), Dar al-Fikr, Beirut.

48 Bisri Mustofa,Tarjamah nidhom Faraaidil Bahiimah fi al qowaaid al fqhiyyah, (Kudus :Maktabah wa mathba'ah menara kudus), hlm. 87 
Al-Qur'an dan Terjemahanya.

A. W. Munawwir, 2002, Kamus alMunawwir Arab-Indonesia

Terlengkap, Pustaka Progressif , Surabaya.

Imam al-Qodhi, 2008, Bidayatul Mujtahid wa Nihayatul Muqtashid (Juz II), Dar al Fikr, Beirut.

Kamus Besar Bahasa Indonesia

Off ine Versi 1.1 Freeware,2010

by Ebta Setiawan.

Karsayuda, 2006, Perkawinan Beda

Agama, Total Media Yogyakarta, Yogyakarta.

K.M Smith Rhona dan Njal Hostmaelingen, 2008, Hukum HAM, Pusat Studi Hukum dan HAM Universitas Islam Indonesia, Yogyakarta.

Mustofa Bisri, Tarjamah Nidhom

Faraaidil Bahiimah fi al Qowaaid

al Fiqhiyyah, Maktabah wa mathba'ah menara kudus, Kudus.

M. Quraish Shihab,2008, M.Quraish

Shihab Menjawab - 1001 Soal Keislaman yang Patut Anda Ketahui, Lentera Hati, Jakarta. 2002, Tafsir Al-

Misbah (Volume 9), Lentera Hati, Jakarta.

Solly Lubis, 2001, Ilmu Negara, Mandar Maju, Bandung.

Undang-Undang Dasar R.I Tahun 1945, Pustaka Mandiri, Surakarta.

Undang-Undang R.I Nomor 1 Tahun 1974 Tentang Perkawinan dan
Kompilasi Hukum Islam, 2010, Kesindo Utama, Surabaya

Zuhdi Muhdhor, 2003, Kamus Kontemporer (al-Ashri) ArabIndonesia, Multi Karya Grafka, Yogyakarta.

Deni K. Yusup, Kodif kasi UU No.39 Tahun 1999, dimuat dalam http:// dkyusup.blogspot.com/2008/04/ kodif kasi-uu-no-39-tahun-1999. html, di akses pada tanggal 22 Januari 2012.

Faeshol Jamaluddin, Analisis Fatwa MUI Nomor :4/Munas VIII MUI/8/2005 tentang perkawinan beda agama, dimuat dalam http://idb4.wikispaces.com/file/ view/bu4001.pdf, diakses pada tanggal 23 Januari 2012

Fakta Empiris Nikah Beda Agama di ttp://blog.umy.ac.id/ retnoeno/2012/01/07/faktaempiris-nikah-beda-agama/, diakses pada tanggal 23 Januari 2012

Imam Hidayat, Pengertian, macam dan Jenis HAM/HAM yang Berlaku Umum Global, dimuat dalam http://imamcubluxhidayat. blogspot.com/2011/02/ pengertian-macam-dan-jenishak-asasi.html, diakses pada tanggal 22 Januari 2012.

Masri Elmahsyar Bidin, Prinsip Hubungan Muslim dan Non Muslim dalam Pandangan Islam, di muat dalam http://www.google. co.id/url?sa=t\&rct=j\&q=penger 
Pernikahan Beda Agama Ditinjau dari....., Ahmadi, Marzha, Muhammad

tian+ahli+kitab+dalam+islam \& source $=$ web $\& c d=1 \&$ ved $=0$ CB0 QFjAA\&url=http\%3A\%2F\%2Fw ww. ditpertais.net\%2Fannualco nference\%2Fancon06\%2Fmak alah\%2FMakalah\%2520Masri. doc\&ei=gs4cT9mHJoK4rAeys OGEDQ\&usg=AFQjCNHoOxR 3-aLet3wVScgtKoQm7XcO3A, diakses pada tanggal 22 januari 2012.

Ronald George Salawane, Pendapat Para Ahli Tentang HAM di muat dalam http://nalhackerblog. blogspot.com/2010/03/ pendapat-para-ahli-tentangham.html, di akses pada tanggal 22 Januari 2012. 